\title{
First Appearance of Mendeleev's Periodic System of Elements in Croatian Chemistry Textbooks
}

\author{
Vanja Flegar, ${ }^{1, *}$ Suzana Inić ${ }^{2}$
}

\footnotetext{
1 The Institute of the History and Philosophy of Science, Croatian Academy of Sciences and Arts, Ante Kovačića 5, HR-10000 Zagreb, Croatia

2 University of Zagreb Faculty of Pharmacy and Biochemistry, Ante Kovačića 1, HR-10000 Zagreb, Croatia

* Corresponding author's e-mail address: vanja@hazu.hr
}

RECEIVED: October 17, 2018 * REVISED: November 27, 2018 * ACCEPTED: December 1, 2018

\begin{abstract}
The first reception of Mendeleev's periodic table of elements and its first mention and publication in Croatian chemistry textbooks is explored. First recognition of Mendeleev's work can be seen in the Croatian chemical community through the act of Yugoslav Academy of Sciences and Arts which elected Mendeleev as an honorary member (1882). Julije Domac, a pharmacist, a chemist and university professor of pharmacognosy at Zagreb University published his textbook The Inorganic Chemistry for Senior Real-High School Classes (Zagreb, 1901) which is the first textbook written in Croatian language that includes the periodic system table. Gustav Janeček, professor of chemistry at Zagreb University, deserves the most credit for accepting and promoting the periodic system within Croatian chemistry. First university textbook of chemistry in Croatia Chemistry I, General, (Zagreb, 1919), written by Janeček, also includes the periodic table. Croatian scientific community accepted and understood the significance of the Mendeleev's periodic system of elements.
\end{abstract}

Keywords: periodic system of elements, Dmitri Ivanovich Mendeleev, Croatian chemistry, Julije Domac, Gustav Janeček, chemistry textbooks.

\section{INTRODUCTION}

$\mathbf{T}$ HE year 2019 marks the $150^{\text {th }}$ Anniversary of the Mendeleev's original discovery of the periodic system of elements based on atomic weights (1869). It also marks the $185^{\text {th }}$ anniversary of Mendeleev's birth. It is a known fact that Russian chemist Dmitri Ivanovich Mendeleev (1834 - 1907) wrote a letter, which was dated in February 1869 to prominent chemists in Russia and abroad, to present his table An Attempt at a System of Elements Based on Their Atomic Weight and Chemical Analogies (1869), with the formulation of the periodic law of elements. His first paper that presented the discovery of the periodic law The Correlation of the Properties and Atomic Weights of the Elements (1869) was read in a meeting of the Russian Chemical Society on March 6 by his friend and colleague Nikolai Ivanovich Menshutkin (1842 - 1907). The paper was published in the first volume of Society's journal in May. Chemical elements in Mendeleev's table were sorted by increasing atomic weight, and into groups depending on the relevant chemical features. Mendeleev's table was published the same year in the respectable German Journal für praktische Chemie, accompanied with an abstract of his earlier report to Russian Chemical Society (Figure 1). Upon the publication of the periodic table, Mendeleev continued his work to improve it and published more papers on this subject.

Ueber die Beziehungen der Figenschaften zu den Atomgewiohter der Flemente. Von D. Mendelejeff. - Ordnet man Elemente nach zunehmenden Atomgewichten in verticale Reihen so, dass die Horizontalreihen analoge Elemente enthalten, wieder nach zunehmendem Atomge-
wicht geordnet, so erhält man folgende Zasammenstellung, aus der sich wicht geordnet, so erhält man folgende Zasam.
einige allgemeinere Folgerungen ableiten lassen.

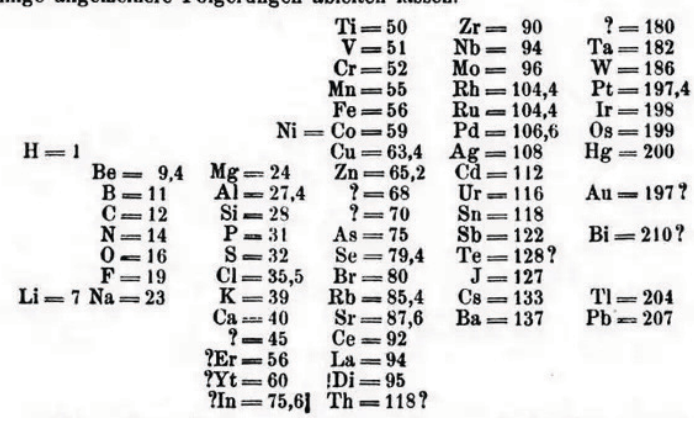

Figure 1. Mendeleev's periodic table published in the Zeitschrift für Chemie (1869). 
A detailed insight into the periodic law and Mendeleev's table of elements was published in 1871 in the Liebigs Annalen journal, titled The Periodic law of The Chemical Elements. Mendeleev explained his periodic law, showed how it could correct the atomic weights of several elements and predicted the properties of some undiscovered elements in this article. Some of Mendeleev's predicted elements were soon discovered, gallium (1875), scandium (1879) and germanium (1885), and this lead to a general acceptance of Mendeleev's periodic system. By the end of the $19^{\text {th }}$ century noble gasses were discovered and then incorporated into the periodic system in the beginning of the $20^{\text {th }}$ century. This lead to another confirmation of the periodic system. ${ }^{[1-6]}$

The history of science, mainly through the history of chemistry, studies the discovery of the periodic system of elements, as well as its significance for the further scientific development, with special interest. Recently published Early Responses to the Periodic System (2015) brings comparative analysis of the reception of the periodic system of elements in most European countries. ${ }^{[7]}$

The reception of the periodic system of elements in European countries has its specifities and differences. In Russia the reception of the periodic system is linked to Mendeleev and the first textbook where it appears is his Osnovy khimii (1868-1871, first edition).

In Germany we can follow the priority dispute between Mendeleev and Lothar Mayer (1830 - 1895) regarding the periodic system. The first textbook in which the periodic system appears in Germany is Victor von Richter's, Kurzes Lehrbuch der Anorganischen Chemie wesentlich für Studirende auf Universitäten und Polytechnischen Schulen sowie zum Selbstunterrichte (1875). ${ }^{[8]}$ Viktor Richter $(1841$ - 1891) published his textbook in Warsaw, Poland, in 1874. ${ }^{[9]}$ Next year the textbook was translated to German language.

In Serbia, Sima M. Lozanić (1847 - 1935), professor of chemistry at the University of Belgrade, had introduced the periodic system into the second edition of his textbook of inorganic chemistry (1880), in which he clearly pointed out the importance of the periodic system for science and teaching. It was the first university textbook, in Serbia, in which the periodic system was mentioned. $[10,11]$

Similarly, as in Croatia, the reception of the periodic system of elements Czech Lands is linked with one chemist, Bohuslav Brauner (1855 - 1935). The first textbook in Czech in which we can trace the appearance of the periodic system was written by Vojtěcha Šafaříka Rukovět chemie pro vysoké učení české. Díl l. Chemie anorganická (1878).[12]

However, a complete study that would examine the recognition of Mendeleev's periodic system by the scientific community in Croatia, including the specific development of chemistry and natural sciences in Croatia has not been published yet. We have therefore investigated and presented in this paper the introduction of Mendeleev's periodic system of elements in Croatian chemistry textbooks at high school and university level. ${ }^{[13,14]}$

\section{CROATIAN CHEMISTRY IN THE PERIOD OF MENDELEEV'S PUBLICATION OF THE PERIODIC SYSTEM}

Following the abolishment of the Jesuit Zagreb Royal Academy of Science and its Philosophy Course in 1850, high school natural science classes have not been held in Croatia for over quarter of a century. These classes were taught within real-high school curriculum. Due to political Bach's absolutism (1852 - 1859) the classes were held in German language only, and German textbooks were used. On 27 September 1861, the Croatian Parliament decided to print and publish Croatian textbooks, and to introduce Croatian language into education system. The first original chemistry textbook in Croatian language, Obća kemija za male realke (General Chemistry for Junior Real-High Schools), was published in 1866. ${ }^{[15]}$ Its author, Pavao Žulić (1831 - 1922),

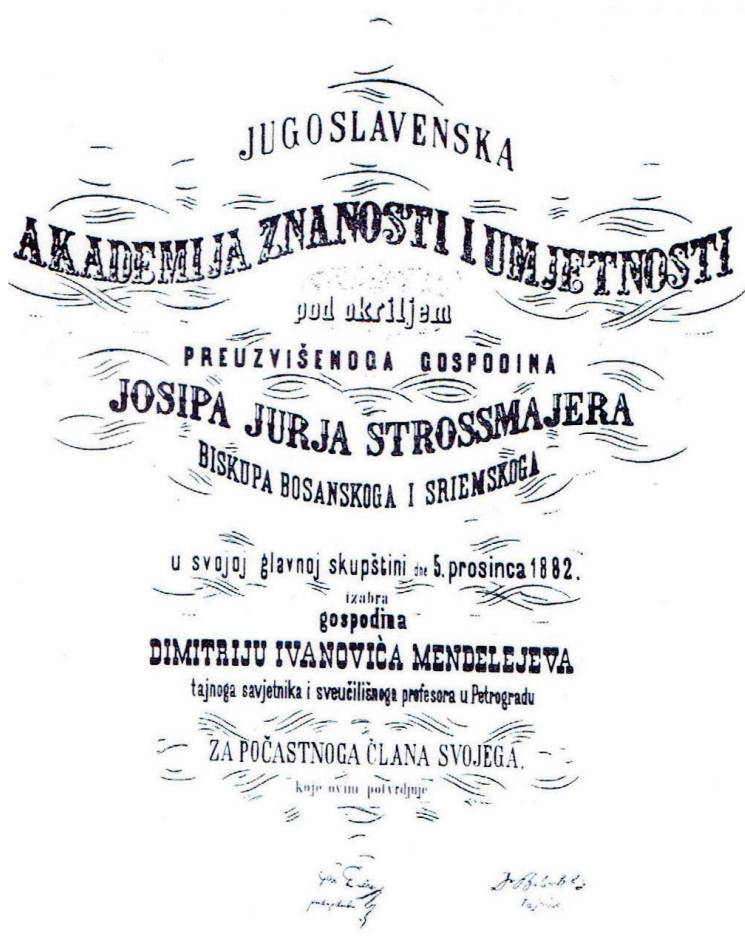

Figure 2. Acknowledgment to Dmitri Ivanovich Mendeleev on election as an honorary member of the Yugoslav Academy of Sciences and Arts in 1882. 
was a professor at Zagreb Senior Real-High School. However, he soon realized that some claims in the textbook were outdated, and 11 years later (1877) he published a new, contemporary textbook Uputa u kemiju za velike realke (Introduction to Chemistry for Senior Real-High Schools). ${ }^{[16]}$ Despite the fact that this textbook was published after Mendeleev's publications concerning the periodic system, the second edition of Žulić's chemistry textbooks does not include information on the periodic system of elements. The main reason for this is probably because the periodic system was not yet included in the curriculum of chemistry for real-high schools.

In 1874, a modern Zagreb University of Franjo Josip I was founded, and natural science departments at future Faculty of Philosophy were founded two years later (1876). We can follow the development of scientific university chemistry in Croatia and the acceptance of chemical discoveries such as the discovery of the periodic system of elements.[17-19]

Chronologically, Croatian scientific community first recognized Mendeleev's work through former Yugoslav Academy of Sciences and Arts (today Croatian Academy of Sciences and Arts) in 1882. This institution based in Zagreb, the capital city of the Kingdom of Croatia, Slavonia, and Dalmatia within Austro-Hungarian Monarchy, has elected Mendeleev as its honorary member (Figure 2). The Yugoslav Academy of Sciences and Arts in Zagreb was the first European science institution to elect Mendeleev as its member. Later, in the same year, 1882, the Royal Society in London awarded a Davy Medal to Mendeleev as well as German chemist Lothar Meyer. ${ }^{[20-22]}$

\section{MENDELEEV'S PERIODIC SYSTEM IN THE TEXTBOOK ANORGANSKA KEMIJA (INORGANIC CHEMISTRY, 1901) WRITTEN BY JULIJE DOMAC}

Historians of science agree that Julije Domac (1853 - 1928) is the first Croatian chemist in $19^{\text {th }}$ century international science. He graduated pharmacy in Vienna (1874). Upon invitation by world-renowned chemist Adolf Lieben (1836 1914), Domac arrived to Graz University and attained a Ph.D. (1880) under the famous professor Leopold von Pebal (1826 -1887), with a respectable scientific work in organic chemistry, based on chlorine dioxide reacting with hexene from mannitol. Immediately, he independently published this work in Justus Liebigs Annalen (1882). Domac declined

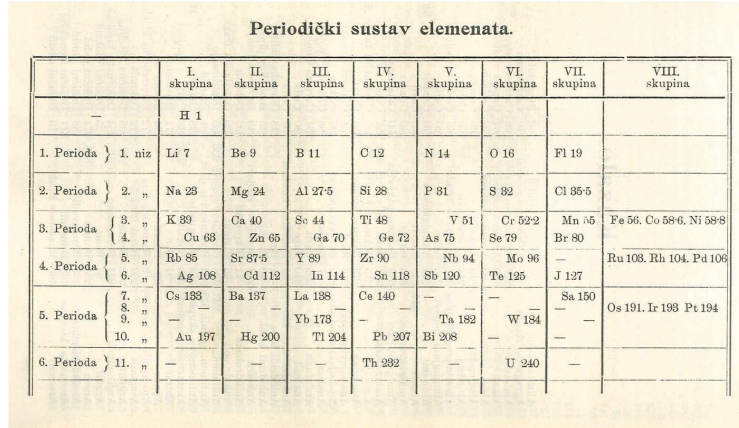

Figure 3. Anorganska kemija (Inorganic Chemistry, 1901) textbook by Julije Domac, showing the first published periodic system of elements table in Croatian chemistry textbook.

Lieben's offer of becoming assistant professor, left Vienna, and returned to the homeland. He spent a certain period as professor at Senior Real-High School in Zemun (1882) and the Senior Real-High School in Zagreb (1886), until Gustav Janeček (1848 - 1929), university professor of chemistry invited him to Faculty of Philosophy at the University of Zagreb, where Domac became a professor of pharmacognosy in 1896. ${ }^{[23]}$

Two of Domac's high school textbooks, written in Croatian language, have greatly contributed to the development of chemistry in Croatia: Organska kemija (Organic Chemistry, Zagreb, 1893, first edition, 1899, second edition, 1906, third edition) and Anorganska kemija za više razrede realnih gimnazija i realaka (Inorganic Chemistry for RealHigh School Senior Classes, Zagreb, 1901). His textbook Anorganska kemija za više razrede realnih gimnazija $i$ realaka is the first Croatian textbook with the table of the periodic system of elements (Figure 3), explaining it and providing additional information on this discovery."

In the foreword of the textbook Domac states that he felt sorry he couldn't use a different methodical and systematic approach in arranging his textbook. He wanted to base the textbook on the periodic system rather than arranging it according to the curriculum programme of chemistry in high schools. The textbook still used the system in which the elements were grouped and presented with regard to their properties, starting with metals. In the foreword Domac lists the books he used when writing his textbook Anorganska kemija, and one of the listed books is Lehrbuch der Anorganischen Chemie (1897) written by famous English chemist and professor at the University of Manchester Henry E. Roscoe $(1833$ - 1915) which follows the periodic system of elements. ${ }^{[24]}$ The periodic table in

\footnotetext{
\# Pharmacy in Croatia reached worldwide level and reputation with Julije Domac. He published Croato-Slavonian Pharmacopoeia (1901) together with Gustav Janeček. Janaček wrote the general chemistry and galenic chapters while Domac wrote the pharmacognosy chapters. The new Croatian pharmacopoeia received positive international reviews.
} 
Domac's textbook incorporates the newly discovered elements which had been added to the periodic table, gallium (Ga, 1875), scandium (Sc, 1879) and germanium $(\mathrm{Ge}, 1886)$ and has empty places for the still unknown elements at that time. Domac writes about the discovery of helium made by Rayleigh and Ramsey (1894), as well as the discovery of other elements such as argon (1894), neon, krypton and xenon (1898). He says that regarding to their properties they form a special group. However, neither the term noble gases is used nor these elements are presented in the periodic table of the time. It was in the year 1904 that Mendeleev agreed with Ramsey to add a group of noble gases to the periodic table. In the presentation of the periodic system of elements, Domac almost completely avoids the historical aspects of the discovery and Mendeleev's predecessors. Since this was a high school textbook in which Domac didn't want to discuss the history of the formation of the periodic system. He focused on explaining the periodic system table in detail, and enumerated everything that can be learned from it.

In the last chapter titled Periodic or Natural System of Elements, ${ }^{[25]}$ the author provides information on basically simultaneous discoveries of periodic system of elements by Russian chemist Dmitri I. Mendeleev and German Lothar Meyer. Other contributions on this topic are not mentioned, nor is further information provided, yet the foundations of the periodic system of elements are explained and the periodic system table is presented. Domac says: This system is based on comprehending that nearly every chemical and physical feature of elements depends on its atomic weight, that these are functions, periodic functions of atomic weights. Furthermore, it is explained that elements in the periodic system are arranged by increasing atomic weight, and their features modify when analog chemical features appear following a certain number and a certain difference in atomic weight. If this sequence is broken at these points, and elements are sorted vertically based on their chemical resemblance, natural groups appear. However, emphasizes Domac, in order to keep this natural sequence, it is necessary to leave some empty spaces to probably be filled in with the unknown elements of the time. The form of the periodic table in the textbook corresponds to the form of the periodic table which is presented in other European chemistry textbooks of the time. ${ }^{[7-12]}$ In the table provided by Julije Domac's Anorganska kemija, hydrogen stands independently, and the following two sequences each create a periodic group of seven elements. Beneath lithium $(\mathrm{Li}=7)$ following the increase of atomic mass by 16 units, comes sodium $(\mathrm{Na}=23)$, followed by potassium $(\mathrm{K}=39)$ at another increase of atomic weight by 16 units. This group is continued by rubidium $(\mathrm{Rb}=85)$ that defies this regularity, and is 46 units heavier, while cesium ( $C s=133)$ comes at 47 units from rubidium. This is the alkali metal group, followed by alkaline earth metals with similar properties. Furthermore, periodic groups are described in detail, pointing out that the sixth group consists of only two discovered elements, thorium ( $T h=232$ ) and uranium $(U=$ 240). This text includes group names, and elements' valence by groups. At the end of the chapter, Domac concludes that elements' properties are undoubtedly periodic functions of their atomic weight suggesting that the atoms of elements are not the smallest, indivisible particles, but aggregations or different grade of condensation of the same substance or pre-matter. The contemporary knowledge of chemistry could not provide a clear answer on this pre-matter, but it was definitely not hydrogen, as it was presumed by Prout. Domac supported the atomic theory. In the first chapter of his book under the subtitle Theory about smallest particles. Molecules and atoms Domac explains how the smallest particles that form elements are atoms which cannot be divided further. However, in the chapter about the periodic system contemporary ideas about atomic structure are presented. Taking into consideration that the experiments regarding the discovery of electron were conducted in the year 1897. by J. J. Thomson (1856 - 1940) and results were published in the following years we can conclude that Domac was informed about these new discoveries when he was writing his textbook. He states that he used some other articles in writing his textbook, but he did not specify them precisely. We can assume these were articles that brought new insights into the structure of the atom, including the knowledge that atoms are not indivisible particles.

Textbook Anorganska kemija is important because we can follow the development of chemistry teaching in Croatia which had just begun to form at higher university level. Domac was an excellent chemist who had studied, learned and worked abroad and collaborated with famous chemists of the time. It is therefore understandable that he was the one who first introduced the periodic system table in Croatian chemistry textbooks.

\section{GUSTAV JANEČEK AND MENDELEEV'S PERIODIC SYSTEM OF ELEMENTS}

The history of chemistry in Croatia cannot be written without mentioning Gustav Janeček, a chemist and pharmacist of Czech origin, who is considered the father of modern chemistry in Croatia. Gustav Janeček moved to Zagreb in 1879, and won the tender for professor of chemistry at Faculty of Philosophy, University of Zagreb. He left an indelible mark in Croatian science. His scholarly and scientific work laid the foundations not only of Croatian 
chemistry, but also Croatian pharmaceutics and pharmaceutical industry. He is one of the founders of the Pharmaceutical Teaching Course (1882), the predecessor of modern Faculty of Pharmacy and Biochemistry, University of Zagreb. He is credited for building two chemistry departments that included chemical laboratories used in chemistry courses, but also allowed various scientific research. Janeček was the first in Croatia to conduct chemical analysis as a court expert, and is therefore honoured with the title of the founder of Croatian forensics. [26]

Since 1888, professor Janeček has been dedicating a part of his lectures in general chemistry to Mendeleev and the periodic system of elements, while his lectures in inorganic chemistry are in compliance with this system. ${ }^{[27]}$

Fran Bubanović (1883 - 1956), his student and also professor of chemistry at the newly founded School of Medicine in Zagreb (1917), writes: In this year of my studies, professor Janeček has once again obligated me and all of his students by clearly and extensively presenting the natural periodic law on chemical elements... he implanted into our souls not only the understanding of importance and magnitude of the periodic law of elements, but also a sincere and deep reverence and enthusiasm for great Slavic scholar and chemist, Dmitri Ivanovich Mendeleev, who discovered and explained this major, basic law of elements. [28]

Janeček introduced the importance and significance of the periodic system of elements not only to the students, but to a wider academic community in Croatia as well. On $8^{\text {th }}$ February 1908, which is Mendeleev's birthday, he held a lecture on Dmitri Ivanovich Mendeleev at the Yugoslav Academy of Sciences and Arts Department of Mathematics and Natural Sciences gathering, speaking in detail on Mendeleev's scientific career and achievements. Professor Gustav Janeček deeply appreciated Mendeleev and his scientific contribution, explaining that the second edition of Mendeleev's textbook Osnovy khimii (1872), was his favourite reading. ${ }^{[29]}$ Janeček met Mendeleev in St. Petersburg and continued correspondence. ${ }^{[30]}$

The first university chemistry textbook in Croatian language was written by Gustav Janeček, Kemija I. Opći dio (Chemistry I, General, Zagreb, 1919). ${ }^{[31]}$ Regarding the classification of elements Janeček mentions the contributions of Johann Wolfgang Döbereiner (1780 1849) and series of chemical principles in triads, in the chapter titled Division (Classification) of Chemical Principles. Janeček states that the issues regarding the classification of elements were of interest to Gladstone, Cooke, Pettenhoffer, Krems, Dumas, Lenssen, Odling, Newlands, Chaurtois, and others, but also states that their efforts were incomplete and unrewarded, and that it was Mendeleev who finished the job. Janeček presents the original Mendeleev's table, as published in 1869, and afterwards the modified table used in 1914. He quotes eight points listed by Mendeleev, which are used to create the periodic system of elements. He also states that Mendeleev predicted the discovery of elements called ekaboron, eka-aluminium, and eka-silicon. These discoveries were not long in waiting: gallium was discovered as Mendeleev's eka-aluminium (1875), scandium as Mendeleev's eka-boron (1879), germanium as eka-silicon (1885). Future discoveries of noble gases found their natural place in the periodic system of elements, as group zero (1904), and are included in this textbook, unlike in the Domac textbook in which there is no noble gases group. By inspecting the table (Figure 4) we can observe that Janeček has different atomic weights of some elements $(\mathrm{Li}, \mathrm{U})$ from those Domac has in his textbook. This is because the development of experimental methods resulted in new values of atomic weights. The form of the periodic table remains the same, the short period form, with elements divided into two sections in each group except the eight, which has three sections. We can also see that Janeček's version of the periodic system does not include hydrogen. There is no explanation for this given. Janeček writes about hydrogen in his textbook and also has it listed as an element in a table where he provides atomic weights. There is a probability that hydrogen was left out of the periodic table by mistake during graphical editing of the periodic table as it stands alone in the first period.

Janeček's textbook follows a different approach then Domac's one. Janeček is focused on historical development of concepts and ideas in chemistry. His textbook is still not arranged according to the periodic system of elements. In the foreword of his textbook Janeček, writes that current

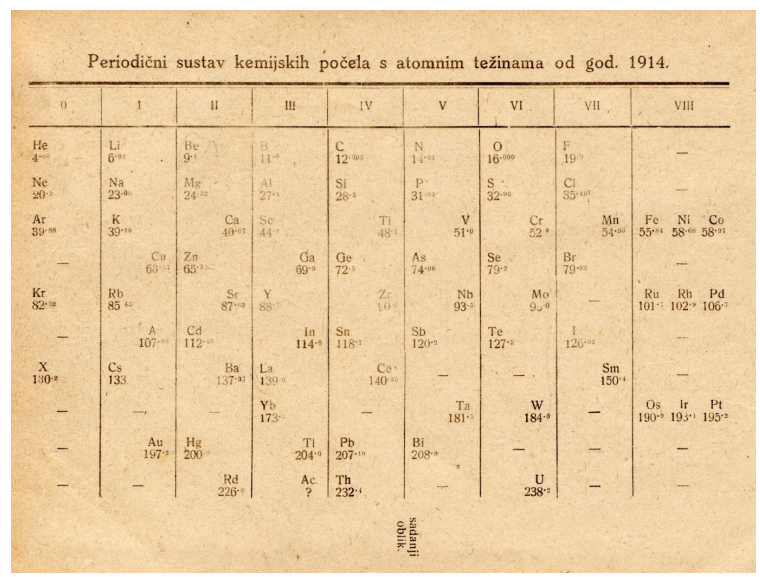

Figure 4. Kemija I, Opći dio (Chemistry I, General, Zagreb, 1919) written by Gustav Janeček showing the periodic system of elements table from 1914, with noble gases added as a group zero. 
situation regarding publishing of books does not allow him to publish a complete edition of general, inorganic and organic textbook, which he has long been working on. So, this current textbook is written and compiled so that his students could follow his basic chemistry classes. Unfortunately, Janeček has never published the rest of his textbooks.

\section{CONCLUSION}

The reception of the periodic system of elements from its discovery to its validations was present in Croatian chemical community. About fifteen years have passed from the time of the first publication of the Mendeleev's periodic table and the periodic law (1869) until we can follow its dissemination in Croatia. This reception and dissemination takes place after the discovery of elements predicted by Mendeleev in his early work and tables. Croatia was the first European country to elect Mendeleev as an honorary member into a scientific institution (1882), Yugoslav Academy of Sciences and Arts (today Croatian Academy of Sciences and Arts).

Until the University in Zagreb was restored in 1874, chemistry in Croatia was only taught at a lower level, as a part of real-high school's curriculum. The first Croatian textbook presenting the periodic system of elements was Anorganska kemija (Inorganic Chemistry for Real-High School Senior Classes, 1901), written by Julije Domac. Gustav Janeček wrote the first Croatian chemistry textbook for university students Opća kemija, I. dio (Chemistry I, General, 1919) which also incorporates the periodic system. It has been shown that both tables have the same form. The primary difference between the two of them is regarding the noble gas group which Janeček's table from 1914 has and Domac's table printed in the year 1901 does not have. At the same time the discovery of noble gases is described in the textbook Anorganska kemija. The noble gas group was introduced to the periodic table in the year 1904.

As it was pointed out in the article, historical context in Croatia was not favourable to the scientific development until a modern Zagreb University was founded in the year 1874. It is therefore no surprise that the reception of the contemporary scientific opinions came later in Croatia then in other European countries. The discovery of the periodic system of elements, and the confirmation of its enduring validity, through discovery of the new elements and all noble gases, occurs simultaneously with the development of the chemistry in Croatia. These discoveries were applied in the educational process within a few years after their discoveries. The future textbooks, published for real-high schools and universities, monitor the development of the periodic system of elements and provide up to date tables. Chemistry lectures in Croatia did not fall behind the scientific findings related to the periodic system. Considering the circumstances, it can be concluded that the Croatian scientific community accepted and understood the significance of the Mendeleev's periodic system of elements.

Acknowledgment. The paper was made under the project Croatian Philosophy and Science in the European Context from the $12^{\text {th }}$ to the $20^{\text {th }}$ century which is supported by the Croatian Science Foundation. Preliminary results of the research were presented at the symposium 24. hrvatski skup kemičara i kemijskih inženjera (Zagreb, 2015), Odraz Mendeljejevog periodnog sustava elemenata u hrvatskoj kemiji (Reflection of Mendeleev's periodic table of elements in croatian chemistry, V. Flegar, S. Paušek-Baždar).

\section{REFERENCES}

[1] D. I. Mendeleev, Periodicheskii Zakon, (Ed.: B. M. Kedrov), Moscow, 1958.

[2] D. Mendeleev, Zh. Russ. Khim. Obshch. 1969, 1, 60.

[3] D. Mendeleev, Zeitschrift für Chemie 1969, 12, 405.

[4] W. B. Jensen, Mendeleev on the Periodic law, selected writings, 1869-1905, Dover publications, 2005.

[5] D. Mendelejeff, Annalen der Chemie und Pharmacie 1871, 8, Supplementband, 233.

[6] E. Scerri, The periodic table Its Story and Its the Significance, Oxford University Press, Oxford, 2007.

[7] Early Responses to the Periodic System, (Eds. M. Kaji, H. Kragh, G. Pallo), Oxford University Press, Oxford, 2015, pp. 1-121.

[8] V. Richter, Kurzes Lehrbuch der Anorganischen Chemie wesentlich für Studirende auf Universitäten und Polytechnischen Schulen sowie zum Selbstunterrichte, Cohen, Bonn, 1875.

[9] V. Richter, Uchebnik neorganicheskoj khimii po novejshim vozzreniyam, Tipografiya Ivana Yavorskog, Warsaw, 1874.

[10] S. M. Lozanić, Hemija sa gledišta moderne teorije. Prvi deo. Neorganska hemija. Second edition, Izdanje i štampa državne štamparije, Beograd, 1880, pp. 124-130.

[11] V. M. Mićović, Odjek otkrića periodnog sistema u Srba i Hrvata, (Ed. P. Stevanović), Srpska akademija nauka i umetnosti, Beograd, 1969.

[12] V. Šafařík, Rukovět' chemie pro vysoké učení české. Díl I. Chemie anorganická, Slavík a Borový, Praha, 1878.

[13] N. Raos, Kem. Ind. 2011, 60, 633.

[14] N. Raos, Bull. Hist. Chem. 2012, 37, 24. 
[15] P. Žulić, Obća kemija za male realke, Narodna tiskara dra. Ljudevita Gaja, Zagreb, 1866.

[16] P. Žulić, Uputa u kemiju za velike realke, Nakladom i troškom Kr. Dalm. Hrv. Slav. Zemaljske vlade, Zagreb, 1877.

[17] D. Grdenić, Croat. Chem. Acta 1975, 47, A36.

[18] I. Senčar-Čupović, Kem. Ind 1989, 38, 485.

[19] I. Senčar-Čupović, Ambix 1990, 37, 74.

[20] H. Iveković, Kem. Ind. 1969, 12, 802.

[21] H. Iveković, Bulletin Scientifique 1969, A14, 878.

[22] Lj. Barić, Collection of Third Symposium on Science History Works. Natural Sciences and Their Application in Late $19^{\text {th }}$ and Early $20^{\text {th }}$ century in Croatia; On Mendeleev's Election as a Honorary Member of Yugoslav Academy of Sciences and Arts, Croatian Society of Natural History, Department of Science History, Zagreb, 1981, pp. 159-169.

[23] S. Inić, N. Kujundžić, Julije Domac (1853-1928) Život i djelo, Hrvatsko farmaceutsko društvo, Farmaceutskobiokemijski fakultet Sveučilišta u Zagrebu, Zagreb, 2012.
[24] H. Roscoe, Lehrbuch der Anorganischen chemie, Friedrich Vieweg und Sohn, 1897.

[25] Julije Domac, Anorganska kemija za više razrede realnih gimnazija i realaka, Kr. hrv.-slav. dalm. zemalj. vlada, Zagreb, 1901, pp. 394-397.

[26] Gustav Janeček (1848-1929) Život $i$ djelo, (Ed.: D. Grdenić), Hrvatska akademija znanosti i umjetnosti, Zagreb, 2002.

[27] M. Deželić, Croat. Chem. Acta 1977, 50, Supplementum, 90.

[28] F. Bubanović, Kemijo hvala ti, Zeleni venac, Beograd, 1939, p. 89

[29] G. Janeček, Posmrtna besjeda D. I. Mendeljejevu, Ljetopis Jugoslavenske akademije znanosti i umjetnosti, 1908.

[30] D. Grdenić in Gustav Janeček (1848-1929) Život $i$ djelo, (Ed.: D. Grdenić), Hrvatska akademija znanosti i umjetnosti, Zagreb, 2002, pp. 11-47.

[31] G. Janeček, Kemija I. Opći dio, Obrtnička zadružna tiskara u Zagrebu, Zagreb, 1919. 